ENTREPRENEURSHIP AND SUSTAINABILITY ISSUES

ISSN 2345-0282 (online) http://jssidoi.org/jesi/

2021 Volume 8 Number 3 (March)

http://doi.org/10.9770/jesi.2021.8.3(10)
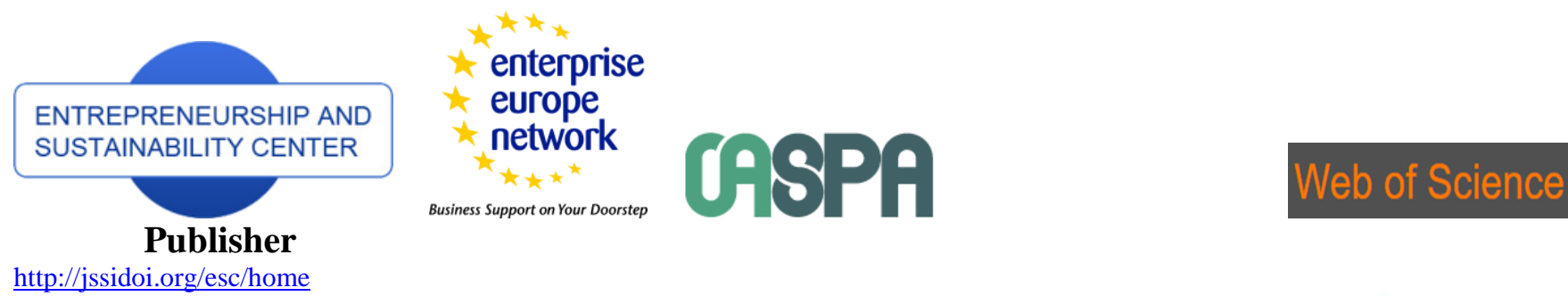

http://jssidoi.org/esc/home

\title{
A STUDY OF ONLINE ENTREPRENEURSHIP EDUCATION UNDER CONDITIONS OF A PANDEMIC
}

\author{
Margarita Išoraitė ${ }^{1}$, Gintarė Gulevičiutė ${ }^{2}$ \\ Vilniaus kolegija / University of Applied Sciences, Saltoniškiu Street 58, Vilnius, Lithuania \\ E-mails: ${ }^{1}$ m.isoraite@vvf.viko.lt ; $^{2}$ g.guleviciute@vvf.viko.lt
}

Received 25 November 2020; accepted 12 January 2021; published 30 March 2021

\begin{abstract}
The purpose of this paper is to investigate the methods and measures of online entrepreneurship education of the Lithuanian population under pandemic conditions. The methodological framework used in the investigation is based on theoretical descriptive, comparative, and analytical methods. Application of a quantitative method is based on an online survey designed specifically for the purposes of the study. The paper analyzes scientific literature of entrepreneurship and related topics, then it discusses the possibilities of online entrepreneurship education under pandemic conditions, the study also determines the expression of respondents' entrepreneurial qualities and abilities. The quantitative study is the main novelty of the research and it is intended in order to produce recommendations for improving the entrepreneurship education of the Lithuanian population under the conditions of a pandemic. The conclusions and recommendations of the research are focused on practical value. Those practical implications could be useful for higher education institutions in order to improve the entrepreneurship education of the Lithuanian population under the conditions of a pandemic by defining teaching methods that promote entrepreneurship in higher education and measures that help develop entrepreneurship.
\end{abstract}

Keywords: entrepreneurship, entrepreneurship education, electronic business.

Reference to this paper should be made as follows: Išoraitè, M., Gulevičiūtè, G. 2021. A Study of Entrepreneurship Education in Internet Space in Pandemic Conditions, Entrepreneurship and Sustainability Issues, 8(3), 179-192. http://doi.org/10.9770/jesi.2021.8.3(10)

JEL Classifications: M12, M21

Additional disciplines: Management, Educology

\section{Introduction}

Currently, various countries in the world are counting losses in connection with the spread of the COVID-19 pandemic. The situation encourages entrepreneurs not to stand still but to start online businesses. The intensive development of youth entrepreneurship, especially its innovativeness, is the key determinant of the modernization

\footnotetext{
* The research is supported by University of Applied Sciences, Lithuania
} 


\section{ENTREPRENEURSHIP AND SUSTAINABILITY ISSUES}

ISSN 2345-0282 (online) http://jssidoi.org/jesi/

2021 Volume 8 Number 3 (March)

http://doi.org/10.9770/jesi.2021.8.3(10)

Make your research more visible, join the Twitter account of ENTREPRENEURSHIP AND SUSTAINABILITY ISSUES: @Entrepr69728810

of the country's economy. New and improved offers, entrepreneurs' products, or technologies allow entrepreneurs to develop new markets and create new wealth. This leads to improving the quality of life as well as creating greater moral and economic freedom; therefore, governments' interest in entrepreneurial development is entirely justifiable. However, global practice shows that there are significant differences between different countries, which include not only the characteristics of the regional mentality, but also numerous other factors that can promote and hinder development of entrepreneurship.

By assessing the importance of entrepreneurship, this article reveals the possibilities of online entrepreneurship education under the conditions of a pandemic and explores the ways of developing the entrepreneurial abilities and skills of the Lithuanian population.

Scientific issue. Pandemic circumstances encourage entrepreneurs not to stand still but to start online businesses; therefore, there is a need to determine online entrepreneurship education, which would assists entrepreneurs in moving their businesses online. Thus, the current situation causes a problem because the concept of the entrepreneuship education under pandemic conditions is not established in scientific literature as well as in practice, which makes it difficult to determine the opportunities and importance of the entrepreneurship education.

The aim of the research is to investigate the methods and measures of online entrepreneurship education of the Lithuanian population under pandemic conditions.

\section{Objectives of the study:}

1. To substantiate theoretically the possibilities of online entrepreneurship education under pandemic conditions by analyzing scientific literature related to entrepreneurial education.

2. To determine the expression of respondents' entrepreneurial qualities and abilities.

3. To create recommendations based on the result of the research in order to improve the entrepreneurship education of the Lithuanian population under the conditions of a pandemic.

Methodology. The paper relies on scientific literature analysis and the quantitative research. Application of a quantitative method is based on an online survey designed specifically for the purposes of the study. The study encompasses theoretical literature analysis as well as systematic and comparative analysis of data obtained with quantitative research.

\section{Theoretical background of the entrepreneurship education}

Entrepreneurship is the ability to create new products, services, and ideas, realize them and make a profit. Both foreign and Lithuanian researchers study the topic of entrepreneurship. Turner (2004) relates entrepreneurship to business skills, whereas Wicham (2006) and Skulskis (2012) connect it with personal skills. Stripeikis (2008) links entrepreneurship to organizational skills, Čiburienė, Guščinskienė (2009) emphasize its connection to both personal and business skills, and Žibènienè (2014) pinpoints that educational and personal skills are closely related to entrepreneurship. Entrepreneurs are considered as one of the growth factors for countries due to the latest industrial, organizational, and technical developments from the global environment countries (Gaddam, 2008). Eroğlu, Piçak (2011) argue that entrepreneurs in different countries usually have some universal features as well as specific ones that are based on their own culture. Schmitt, Husson (2017) define an entrepreneur as a person capable of managing a large database of information and making decisions. De Sordi et al. (2020) present a longitudinal study, where entrepreneurs are characterized by development methods that involve little 


\section{ENTREPRENEURSHIP AND SUSTAINABILITY ISSUES}

ISSN 2345-0282 (online) http://jssidoi.org/jesi/

2021 Volume 8 Number 3 (March)

http://doi.org/10.9770/jesi.2021.8.3(10)

Make your research more visible, join the Twitter account of ENTREPRENEURSHIP AND SUSTAINABILITY ISSUES: @Entrepr69728810

commercial and technological uncertainty, followed by some more complex and unclear initiatives but always safer innovation.

Chowdhury et al. (2019) suggest that entrepreneurship actively contributes to economic growth. As Bruton et al. (2018) argue the growing recognition of entrepreneurship around the world has drawn attention to its cultural ideological foundations. In order to create a business in another country, it is necessary to know in which cultural environment that business will be developed and to know the culture of the other country. Regional cultural differences should be taken into account when analysing entrepreneurial failure (Kuckertz et al, 2020). The discussion emphasizes that entrepreneurship is a multifaceted phenomenon that varies depending on the context, the level of innovation, and its impact on society. Al Issa (2020) states that entrepreneurship needs to be resilient enough to face many challenges. In their articles Kowo et al. (2019) and Al-Hawary, Al-Syasneh (2020) mention that strategic entrepreneurship is the key indicator of economic, technological, and social development.

Shyra et al. (2020) define the need to create secure conditions for the development of entrepreneurship in general. The current global situation, with the prevalence of the coronavirus COVID-19, provides an opportunity to develop and build businesses online and adapt their Key Performace Indicators (KPIs) (Girdzijauskaite et al., 2019).

According to Lascaux, Kolesnikova (2020), entrepreneurial companies need to build trust in their business projects, especially among customers and employees. Bouncken et al. (2020) argue that areas for cooperation are important in the development of entrepreneurship. Küttim et al. (2011) mention that entrepreneurship acquire acceleration of support innovation, creativity and economic growth.

Mahrous et al. (2020) present the characteristics of the organisation's internal environment that support the development of emerging and growing entrepreneurship: collaborative excellence, a deep focus on planning and institutional support. Muñoz-Castro (2019) suggests that while government institutions are of significant importance to multinational entrepreneurs, human capital and motivation are crucial. Raposo et al. (2020) argue that those countries that implement higher level national entrepreneurship systems perform better in terms of their sustainability.

The entrepreneurship education has been the key factor in establishing a necessary link between entrepreneurship and education (Galloway, Kelly, 2009). It is generally defined as a never-ending practice of skill acquisition and idea generation which helps identify and develop business opportunities that are often overlooked because of other appropriate insights and self-esteem. Jones and English (2004) describe entrepreneurship in education as the ability to recognize commercial opportunities and insight, self-esteem, knowledge, and skills to act on them. Gautam, Singh (2015) claim that the entrepreneurship education is the exploration of the source of opportunities and the process of discovery in which a person strives for creativity, takes risks, and turns ideas into action. According to Ayed (2020), entrepreneurial education and innovativeness can evoke entrepreneurial intention. Miranda et al. (2020) analyze the entrepreneurship education in the context of multidisciplinary collaboration: sociology, psychology, philosophy, business, and engineering education. Johann et al. (2020) argue that design thinking is a relatively new methodology in the context of the entrepreneurship education but nonetheless a very important tool for developing entrepreneurial skills when incorporated into the education system.

According to Karimi et al. (2012), the entrepreneurship education is important because it increases economic efficiency, brings innovation to the market, creates new jobs, and raises employment rates. Popularity of entrepreneurship courses has grown significantly among both graduates and undergraduate students. But 


\section{ENTREPRENEURSHIP AND SUSTAINABILITY ISSUES}

ISSN 2345-0282 (online) http://jssidoi.org/jesi/

2021 Volume 8 Number 3 (March)

http://doi.org/10.9770/jesi.2021.8.3(10)

Make your research more visible, join the Twitter account of ENTREPRENEURSHIP AND SUSTAINABILITY ISSUES: @Entrepr69728810

Griffiths et al. (2012) argue that more experimentation and government support for research is needed to improve the teaching of innovative entrepreneurship, as there is little evidence of what works and what does not. Kim et al. (2020) define the special attention to social entrepreneurship education programs, which cultivate social entrepreneurs' abilities to enhance connectivity with all relevant entities of the social enterprise ecosystem.

Chien-Chi et al. (2020) analyze entrepreneuship education from social entrepreneurship dimension and suggest that social-emotional competence and self-efficacy have a positive effect on entrepreneurial intention. A research based on survey responses from a sample of 740 students of economics, communications, and education, carried out by Rodriguez-Gutierrez et al. (2020), suggests that personal attitudes and perceived behavioural control are positively related to students' entrepreneurial intention. Peña-Ayala,Villegas-Berumen (2020) indicate well-being of the city wherein the institution is located, students' inner concerns related to entrepreneurship, and formal entrepreneurial education taught by the institution as important factors in entrepreneurial affairs. Otache et al. (2020) analyze self-employment intentions as well as paid-employment intentions and define a particularly positive link between both intensions.

Mani (2015) states that the need for entrepreneurship education has been well established in recent research. However, there is a debate about how education should be provided, what should be the students' attitudes towards the entrepreneurship education. There is an ongoing debate on the role of universities and the contribution of business schools to entrepreneurship education (Kirby, 2004). Peric et al. (2020) highlights that not just universities but vocational education should also focus on entrepreneurship background. In the case of COVID-19, higher education institutions have opportunities to contribute to the change by organizing entrepreneurial events. In their research Bacq et al. (2020) state the value of the time-compressed virtual idea blitz in accelerating social entrepreneurial action. Experiential education bridges the gap between theory and practice (Androniceanu, Tvaronavičiené, 2019; Liguori et al., 2020; Androniceanu, 2020; Androniceanu et al. 2020). Artificial intelligence can be an important factor in entrepreneurship education, and the need of interdisciplinary cooperation between computer science, statistics, education, cognition, and robotics can be seen (Yu, 2020).

It should be stated that there is no single definition of entrepreneurship and the entrepreneurships education. There are, however, several common characteristics amongst different entrepreneurship concepts presented in this literature review: personal initiative, ability to mobilise resources, management skills, desire for autonomy, and risk-taking.

Despite the analysis of previous research, the characteristics of the worrying factors of building a business during a pandemic, teaching methods that promote entrepreneurship in higher education, and the measures that help to develop entrepreneurship in higher education are not sufficiently detalized. This study aim is to investigate the methods and measures of online entrepreneurship education of the Lithuanian population under the conditions of a pandemic. Research questions are formulated based on the aim of the study: how to estimate which teaching methods and measures help to develop entrepreneurship in higher education under the conditions of a pandemic?

\section{Online entrepreneurship education during a pandemic research objective and methodology.}

The research employed a quantitative method in a form of an online survey. Questions were based on theoretical analysis and the aim of the research. The questions sought to distinguish how respondents can define entrepreneurship (entrepreneurship definition is analysed in the studies of Turner (2004); Wicham (2006); Skulskis (2012); Stripeikis (2008); Čiburienè, Guščinskienè (2009); Žibėnienė (2014)), which factors are 
ENTREPRENEURSHIP AND SUSTAINABILITY ISSUES

ISSN 2345-0282 (online) http://jssidoi.org/jesi/

2021 Volume 8 Number 3 (March)

http://doi.org/10.9770/jesi.2021.8.3(10)

Make your research more visible, join the Twitter account of ENTREPRENEURSHIP AND SUSTAINABILITY ISSUES: @Entrepr69728810

important in making the decision to start a business (question is based on the studies by Shyra et al. (2020); Muñoz-Castro (2019); Gutierrez et al. (2020); Peña-Ayala,Villegas-Berumen (2020); Otache et al. (2020)), which are the worrying factors of building a business during a pandemic (Kuckertz et al, 2020; Al Issa (2020)), which teaching methods promote entrepreneurship in higher education (Johann et al. (2020); Kim et al. (2020); Bacq et al. (2020); Yu, 2020), which measures can help develop entrepreneurship in higher education (Muñoz-Castro (2019); Gautam, Singh (2015); Ayed (2020)). The binary scales method consisting of binary items that assume one of the two possible values was used.

Quantitative research in respondents' entrepreneurship education was conducted on the basis of quantitative research methods. In this research questionnaire was used as the main data collection tool. This research is practical in nature, and the goal was to conduct an extensive analysis; thus, due to its approach, the research was descriptive and exploratory. Participation in this research was voluntary. Survey had been conducted in September-November, 2020.

Sampling Method. The questionaire was distributed to Lithuanian residents, and the respondents were selected using probability sampling. Required sample was calculated by using http://www.surveysystem.com/sscalc.htm website. The calculation of the sample indicated that the confidence level is 95 per cent, 5 per cent confidence interval, population: 2,669 million (the number of people in Lithuania on 2020 years). The estimated sample was 384. The survey involved 437 respondents. The calculations demonstrated that 437 respondents are a sufficient sample for conducting a reliable research. The samples selected for this study are the male and female genders. The survey involved 437 respondents, of whom $14 \%$ were men and $86 \%$ were women. As the Table 2 indicates, having analysed the demographic characteristics of participants in this survey, most of them were in the age group of over 35 years old (67\%), 23\% of the respondents were in the age range of 19-25. The analysis of the activity of the respondents shows that $66 \%$ of the respondents are working, $19 \%$ of the respondents are working and studying, and $15 \%$ just studying. The vast majority (75\%) of the respondents work in the public sector.

Table 2. The demographic characteristics of the sample

\begin{tabular}{|l|l|l|}
\hline & Frequency & Percentage \\
\hline Gender & & \\
\hline Female & 377 & 86 \\
\hline Male & 60 & 14 \\
\hline Total & 437 & 100 \\
\hline Age & & \\
\hline Under 18 & 10 & 2 \\
\hline $19-25$ & 101 & 23 \\
\hline $26-30$ & 10 & 2 \\
\hline $31-34$ & 17 & 5 \\
\hline 35 and more & 299 & 67 \\
\hline Total & 437 & 100 \\
\hline Status & & \\
\hline Working student & 80 & 19 \\
\hline Employee & 293 & 66 \\
\hline Student & 64 & 15 \\
\hline Total & 437 & 100 \\
\hline
\end{tabular}


ENTREPRENEURSHIP AND SUSTAINABILITY ISSUES

ISSN 2345-0282 (online) http://jssidoi.org/jesi/

2021 Volume 8 Number 3 (March)

http://doi.org/10.9770/jesi.2021.8.3(10)

Make your research more visible, join the Twitter account of ENTREPRENEURSHIP AND SUSTAINABILITY ISSUES: @Entrepr69728810

2 hypotheses were introduced:

1. Respondents' worrying factors of building a business during a pandemic depend on whether the respondent is planning to start business during pandemic.

2. Respondents' evaluation of measures that help develop entrepreneurship in higher education depends on their status (studying, working, or both).

The Spearman's correlation coefficient was calculated using SPSS software in order to determine the interdependence between the two variables to identify and test hypotheses.

\section{Online entrepreneurship education in a pandemic environment research result analysis.}

The respondents were asked, what is entrepreneurship (see Table 3). The respondents had the opportunity to choose from several answer options. $22.3 \%$ of the respondents said it is the ability to create and manage, $14.8 \%$ stated that entrepreneurship is the ability to innovate, $16.3 \%$ stated that entrepreneurship is the ability to create added value, $14 \%$ of the respondents said it was the ability to realize themselves, $15.6 \%$ stated that it is a person's way of thinking as well as personal social, managerial, and personal competencies, $16.7 \%$ of the respondents described entrepreneurship as the ability to make money.

Table 3. Entrepreneurship definition according respondent opinion

\begin{tabular}{|l|l|l|}
\hline Answer options & Number Proportion \\
\hline Ability to create and manage a business & 340 & $22.3 \%$ \\
\hline Ability to innovate & 226 & $14.8 \%$ \\
\hline Ability to create added value & 248 & $16.3 \%$ \\
\hline Ability to realize yourself & 213 & $14.0 \%$ \\
\hline Individual way of thinking and personal social, managerial and personal competencies & 238 & $15.6 \%$ \\
\hline Ability to make money & 255 & $16.7 \%$ \\
\hline Other (please specify) & 3 & $0.2 \%$ \\
\hline
\end{tabular}

In the next question the respondents were asked, what habits they developed during the pandemic. $23.3 \%$ of the respondents said that they started to take more care of their hygiene, $23.1 \%$ said they started buying goods online, $19 \%$ of the respondents started working remotely, $14.4 \%$ of the respondents started spending more time with their families (see Table 4).

Table 4. Respondents' habits under pandemic conditions

\begin{tabular}{|l|l|l|}
\hline Answer options & Number & Proportion \\
\hline Enhanced care for hygiene & 102 & $23.3 \%$ \\
\hline More time to spend with family & 63 & $14.4 \%$ \\
\hline Buy online & 101 & $23.1 \%$ \\
\hline Opt for virtual communication, book reading and online media use & 49 & $11.2 \%$ \\
\hline Focus on a healthier diet and your personal development & 26 & $5.9 \%$ \\
\hline Choose distance job & 83 & $19.0 \%$ \\
\hline Cook according to new recipes & 7 & $1.6 \%$ \\
\hline Other & 5 & $1.1 \%$ \\
\hline Did not answer the question & 1 & $0.2 \%$ \\
\hline
\end{tabular}


ENTREPRENEURSHIP AND SUSTAINABILITY ISSUES

ISSN 2345-0282 (online) http://jssidoi.org/jesi/

2021 Volume 8 Number 3 (March)

http://doi.org/10.9770/jesi.2021.8.3(10)

Make your research more visible, join the Twitter account of ENTREPRENEURSHIP AND SUSTAINABILITY ISSUES: @Entrepr69728810

The respondents were asked, what factors are important in making the decision to start a business. The results of the survey (see Figure 1) show that $57.8 \%$ of the respondents fully agree that an attractive business idea is very important, $47.4 \%$ of the respondents fully agree that obtaining necessary financial resources is of most importance, $18.9 \%$ fully agree that a desire to address a social or environmental issue is the most important factor in making the decision to start a business. $47 \%$ of the respondents agree with the statement that relationships with the right business partner are important in making a decision to start a business, $44 \%$ angree that obtaining the necessary financial resources and best practices are important.

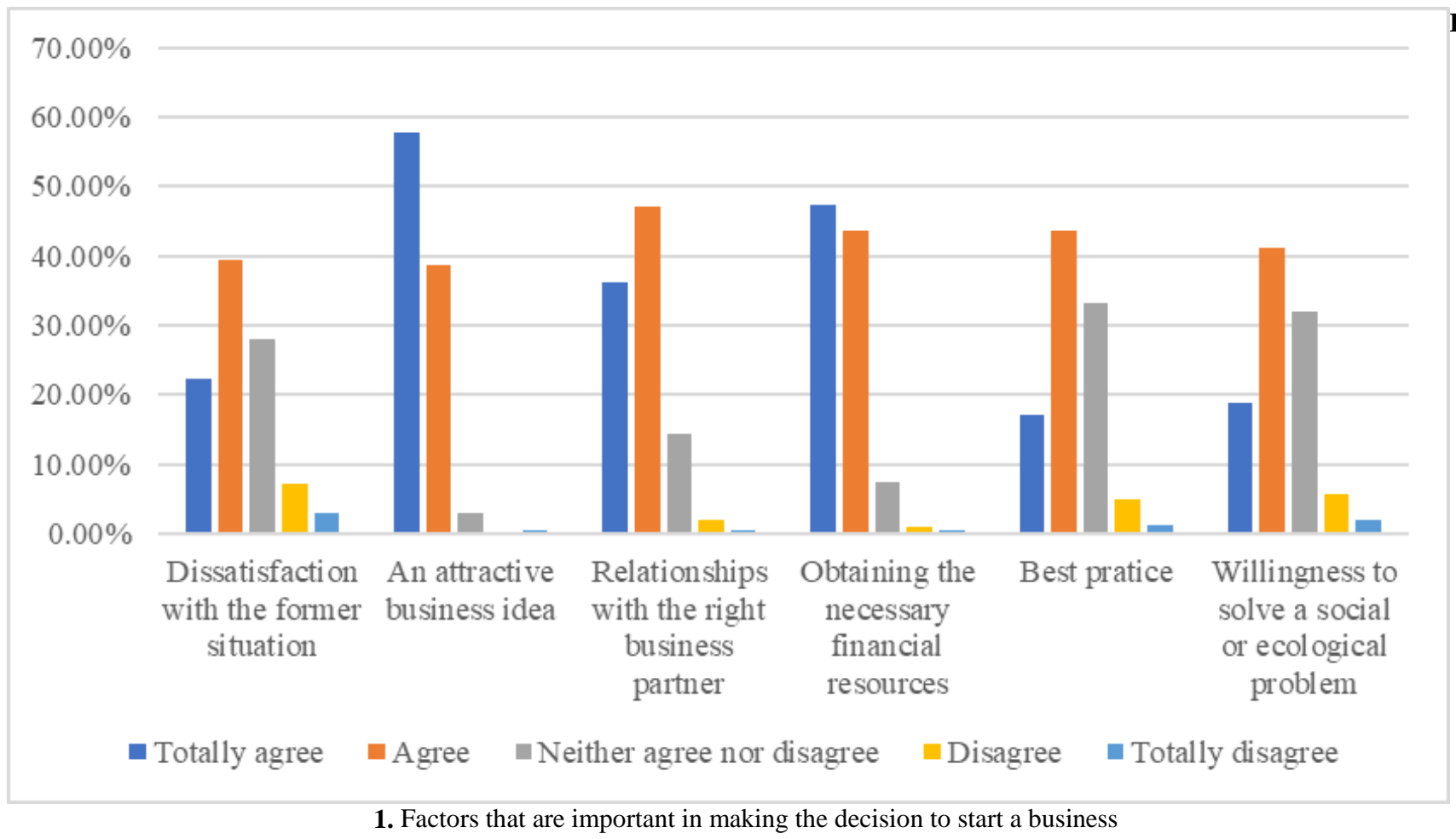
Source: authors

The survey sought to find out what would be the worrying factors of building a business in a pandemic. $47.2 \%$ of the respondents fully agree that being unaware of the income is the most prominent worrying factor. $42.4 \%$ of the respondents fully agree that worrying factors are associated with the risk of losing property, $42.2 \%$ fully agree that it would be the risk of losing money and/or time due to business failure and $37.2 \%$ of the respondents fully agree that it would be connected with the abscence of a permanent job (see Figure 2). 


\section{ENTREPRENEURSHIP AND SUSTAINABILITY ISSUES}

ISSN 2345-0282 (online) http://jssidoi.org/jesi/

2021 Volume 8 Number 3 (March)

http://doi.org/10.9770/jesi.2021.8.3(10)

Make your research more visible, join the Twitter account of ENTREPRENEURSHIP AND SUSTAINABILITY ISSUES: @Entrepr69728810

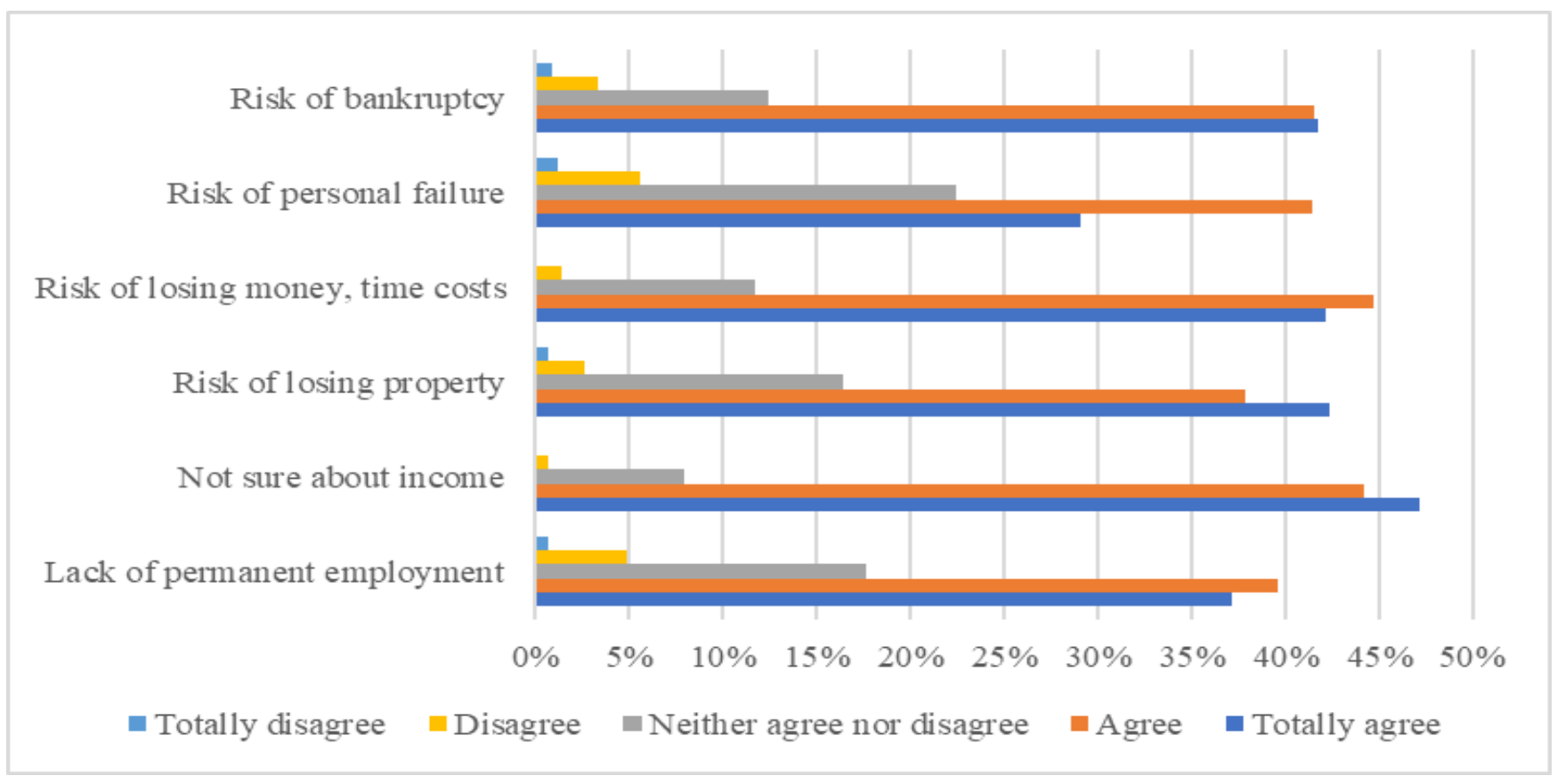

Fig 2. Worrying factors of building a business during a pandemic Source: authors

After the analysis of the worrying factors of building a business during a pandemic, the first hypothesis can be checked. Respondents' worrying factors of building a business during a pandemic depend on whether the respondent is planning to start a business during a pandemic. This hypothesis was selected because in the survey respondents were also asked if they were thinking of setting up a business on the Internet under pandemic conditions. As the results of the survey show, as many as $89 \%$ of the respondents do not intend to start a business during a pandemic, $10.8 \%$ intend to do so.

In order to test the hypothesis, Spearman R - Spearman ordinal correlation coefficient was calculated. In this case it was 0,403236-a weak positive correlation close to the average. The $\mathrm{H} 0$ and Ha were formulated. H0 - the correlation coefficient is equal to zero, or the relationship between the variables is not available, the Ha-the correlation coefficient is not zero, then the relationship between the variables exists. The significance level $\alpha=$ 0,05 (five per cent error) had been selected. In this case P-level-observational significance level ( $\mathrm{p}$-level = $0,00000<\alpha=0,05)$ refers to prove alternative hypothesis Ha and Spearman correlation coefficient is significantly different from zero. Respondents' worrying factors of building a business during a pandemic depend on whether the respondent is planning to start business under the pandemic conditions.

The study aimed to explore what methods would promote entrepreneurship in higher education. $69.6 \%$ of the respondents fully agree or agree that it would be a presentation of content, 56.9\%. of respondents fully agree or agree what it would be a lecture, $69.2 \%$ of the respondents fully agree or agree that it would be a seminar, $78.2 \%$ of the respondents fully agree or agree that it would be a task solving. 86.9\% of the respondents strongly agree or agree that this would be a case study. The results of the study show that many teaching methods are important and promote entrepreneurship. All separate evaluations can be seen in Figure 3. 
Make your research more visible, join the Twitter account of ENTREPRENEURSHIP AND SUSTAINABILITY ISSUES: @Entrepr69728810

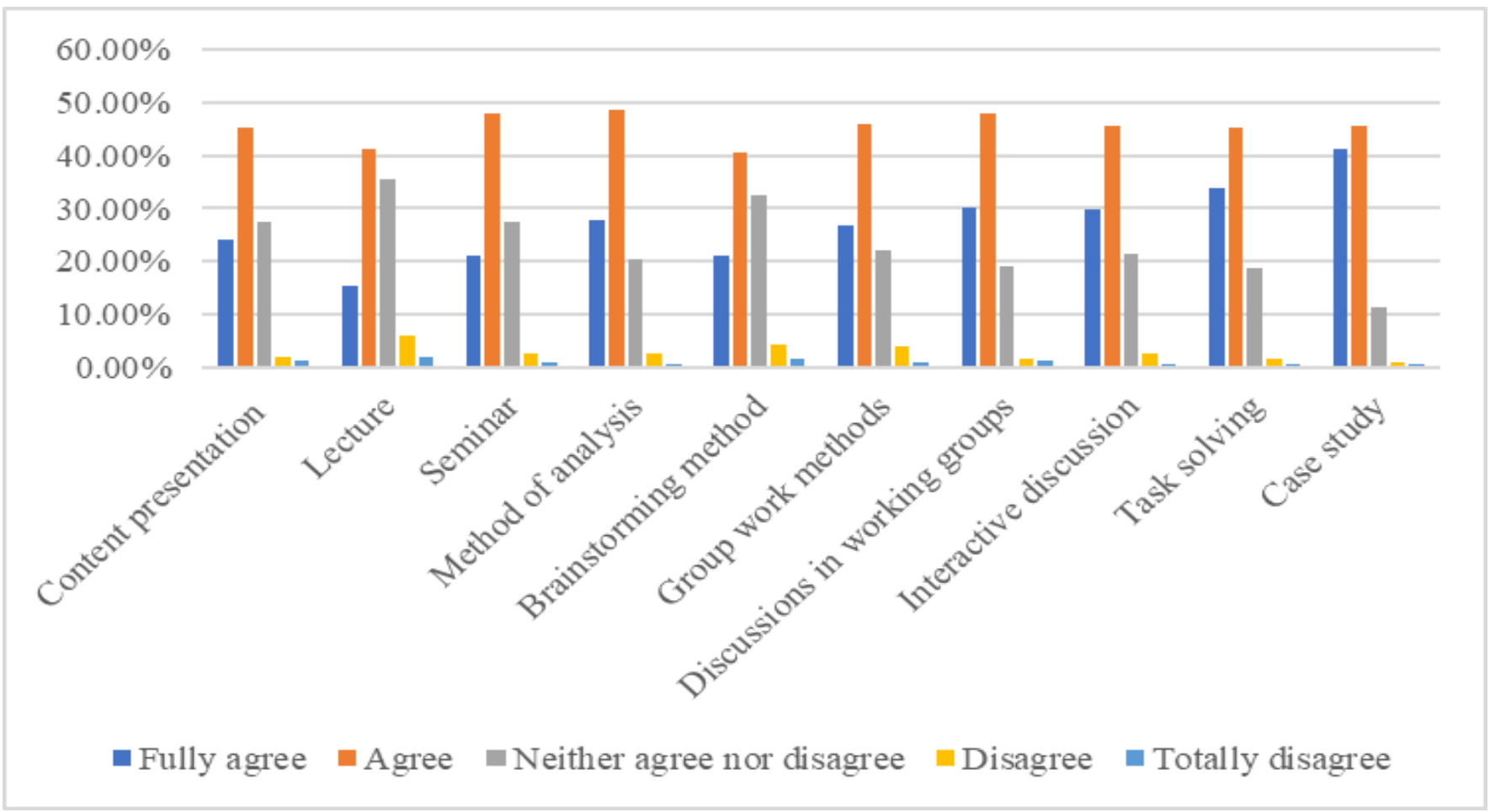

Fig 3. Teaching methods that promote entrepreneurship in higher education Source: authors

Another aim of the study was to find out what are the measures that help to develop entrepreneurship in higher education. $94.2 \%$ of the respondents fully agree or agree that it would be internship in business enterprises. $89.4 \%$ of the respondents fully agree or agree that participation in project activities would be an effective tool, $90.4 \%$. fully agree or agree that it would be communication with experienced entrepreneurs, $83.9 \%$ think that seminars with practical tasks would be a helpful. $83.2 \%$ of the respondents fully agree or agree that opportunity to adopt good practice would be a good way to develop entrepreneurship in higher education. All separate evaluations can be seen in Figure 4. 


\section{ENTREPRENEURSHIP AND SUSTAINABILITY ISSUES}

ISSN 2345-0282 (online) http://jssidoi.org/jesi/

2021 Volume 8 Number 3 (March)

http://doi.org/10.9770/jesi.2021.8.3(10)

Make your research more visible, join the Twitter account of ENTREPRENEURSHIP AND SUSTAINABILITY ISSUES: @Entrepr69728810

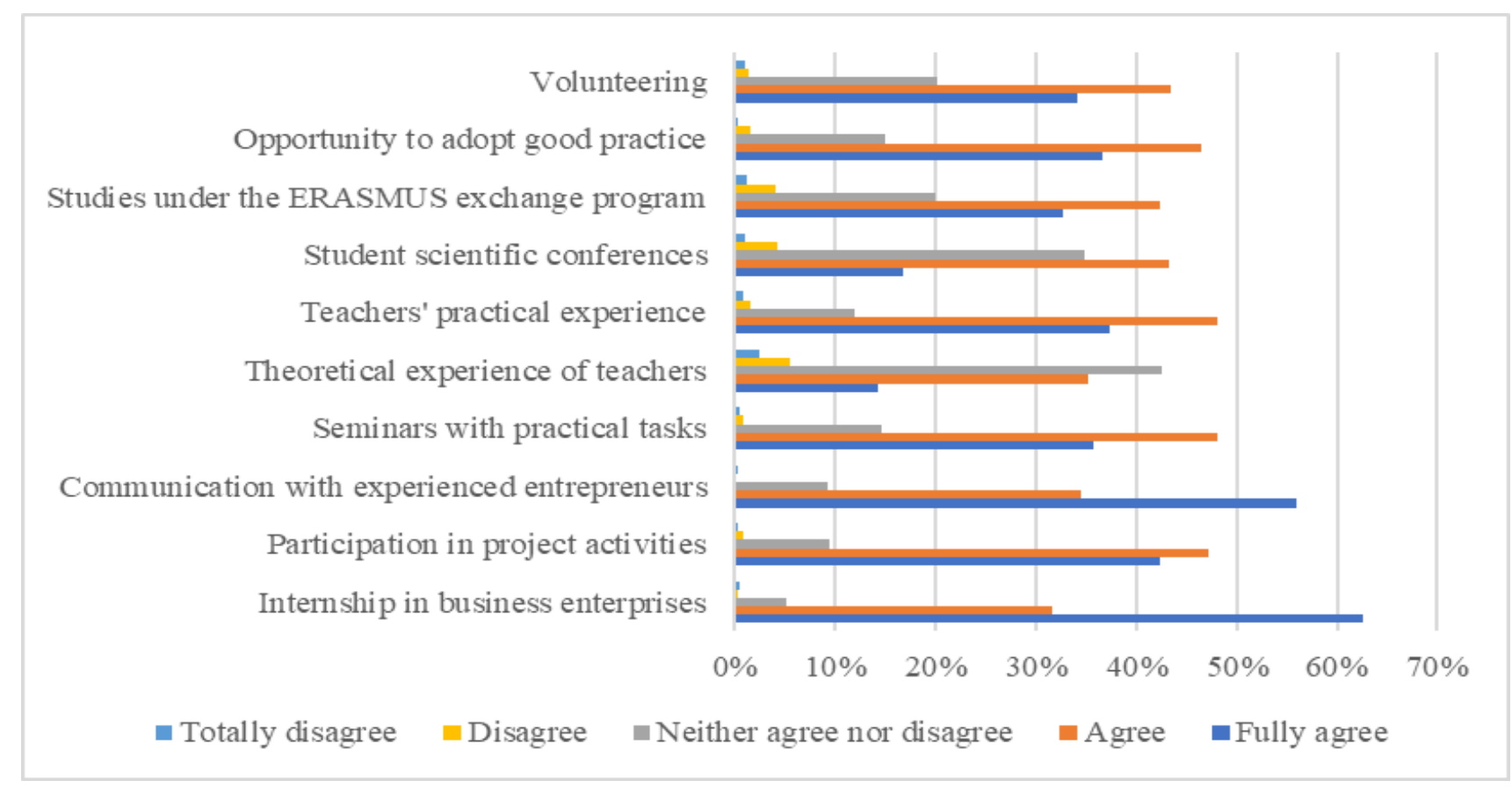

Fig 4. Measures that help develop entrepreneurship in higher education Source: authors

After analyzing the data it was important to approve or to deny the second hypothesis. Respondents' evaluation of measures that help develop entrepreneurship in higher education depends on their status (studying, working or both). In order to test the hypothesis, Spearman R - Spearman ordinal correlation coefficient was calculated. In this case it was 0,602372-medium positive correlation. The H0 and Ha were formulated. H0 - the correlation coefficient is equal to zero, or the relationship between the variables is not available, the Ha-the correlation coefficient is not zero, then the relationship between the variables exists. The significance level $\alpha=0,05$ (five percent error) has been selected. In this case P-level—observational significance level (p-level $=0,00000<\alpha=$ 0,05 ) refers to prove alternative hypothesis $\mathrm{Ha}$ and Spearman correlation coefficient is significantly different from zero. It can be concluded, that respondents' evaluation of measures that help develop entrepreneurship in higher education depends on their status (studying, working or both).

\section{Conclusions}

1. After analyzing the scientific literature of online entrepreneurship education under the conditions of a pandemic it can be stated that there is no single definition of entrepreneurship and of the entrepreneurship education. Personal initiative, the ability to mobilize resources, management skills, the desire for autonomy, and risk-taking are the aspects connected to the concept of entrepreneurship. The entrepreneurship education helps to identify and to develop business opportunities that are often overlooked, to recognize commercial opportunities and insights, to explore the source of opportunities and the process of discovery, to increase economic efficiency, to bring innovation to the market, to create new jobs, and to raise employment rates. 


\section{ENTREPRENEURSHIP AND SUSTAINABILITY ISSUES}

ISSN 2345-0282 (online) http://jssidoi.org/jesi/

2021 Volume 8 Number 3 (March)

http://doi.org/10.9770/jesi.2021.8.3(10)

Make your research more visible, join the Twitter account of ENTREPRENEURSHIP AND SUSTAINABILITY ISSUES: @Entrepr69728810

2. Expression of entrepreneurial qualities and abilities can be defined by factors that are important in making a decision to start a business. An attractive business idea, obtaining necessary financial resources, the desire to solve a social or environmental issue, relationships with the right business partner can be stated as quality measures in making a decision to start a business. Also, entrepreneurial abilities can be connected with approved hyphothesis that respondents' worrying factors of building a business during a pandemic depends on whether the respondent is planning to start business under a pandemic. The uncertainty about the income, the risk of losing property, money and/or time costs due to business failure, and the absenceof permanent job can suppress entrpreneurship abilities.

3. After application of a quantitative study, which was based on an online survey, recommendations in order to improve the entrepreneurship education of the Lithuanian population under the conditions of a pandemic can be prepared by defining teaching methods and measures that promote entrepreneurship in higher education and help develop entrepreneurship in higher education institutions. Case study, task solving, and presentation of content can be defined as the most recommended teaching methods. In order to encourage entrepreneurship, internship in business enterprises, participation in project activities, communication with experienced entrepreneurs are highly recommended to higher education institutions.

Novelty and research limitations. Novelty of the research is based on identifying practical implications which reflect on attributes and factors of teaching methods that promote entrepreneurship in higher education. Also, the entrepreneurship education of the Lithuanian population is analyzed in the context of the COVID-19 pandemic which is creates totally new conditions. Research limitations - the study examined the entrepreneurship education under pandemic conditions only in general terms, and the findings cannot necessarily be applicable to a particular higher education institution. Also, it includes just the population of Lithuania, the scope of further research could include more countries.

\section{References}

Al Issa, H., E. 2020. When grit leads to success: the role of individual entrepreneurial orientation, Business: Theory and Practice, 21, 2, 643-653. https://doi.org/10.3846/btp.2011.38

Al-Hawary, S., I., Al-Syasneh, M., S. 2020. Impact of dynamic strategic capabilities on strategic entrepreneurship in presence of outsourcing of five stars hotels in Jordan. Business: Theory and Practice, 21(2), 578-587. https://doi.org/10.3846/btp.2020.11895

Androniceanu, A. (2020). Major structural changes in the EU policies due to the problems and risks caused by COVID-19. Administratie si Management Public, 34, 137-149. https://doi.org/10.24818/amp/2020.34-08

Androniceanu, A., Kinnunen, J., Georgescu, I. (2020). E-Government clusters in the EU based on the Gaussian Mixture Models. Administratie si Management Public, 35, 6-20. https://doi.org/10.24818/amp/2020.35-01

Androniceanu, A., Tvaronavičienè, M. (2019). Developing a holistic system for social assistance services based on effective and sustainable partnerships. Administratie si Management Public, 33, 103-118. https://doi.org/10.24818/amp/2019.33-06

Ayed, T.L. 2020. Extending the debate over entrepreneurial education effectiveness: the case of a Saudi university, Education and Training, 62(7/8), 805-823. https://doi.org/10.1108/ET-12-2019-0273

Bacq, S., Geoghegan, W., Josefy, M., Stevenson, R., Williams, T. 2020. The COVID-19 Virtual Idea Blitz: Marshaling social entrepreneurship to rapidly respond to urgent grand challenges. Business Horizons, 63(6), 705-723. https://doi.org/10.1016/j.bushor.2020.05.002

Beinoraitè, Š., Drejeris, R. 2014. Population entrepreneurship measurement model. Business: Theory and Practice, 15(3), $199-209$. https://doi.org/10.3846/btp.2014.20 


\section{ENTREPRENEURSHIP AND SUSTAINABILITY ISSUES}

ISSN 2345-0282 (online) http://jssidoi.org/jesi/

2021 Volume 8 Number 3 (March)

http://doi.org/10.9770/jesi.2021.8.3(10)

Make your research more visible, join the Twitter account of ENTREPRENEURSHIP AND SUSTAINABILITY ISSUES: @Entrepr69728810

Bouncken, R.B., Kraus, S., Martínez-Pérez, J.F. 2020. Entrepreneurship of an institutional field: the emergence of coworking spaces for digital business models. International Entrepreneurship and Management Journal, 16, 1465-1481. https://doi.org/10.1007/s11365-020$\underline{00689-4}$

Bruton, G., D., Zahra, S., A., Cai, L. 2018. Examining Entrepreneurship through Indigenous Lenses. Entrepreneurship Theory and Practice, 42(3), 351-361. https://doi.org/10.1177/1042258717741129

Čiburienė, J., Guščinskienė, J. 2009. Youth entrepreneurship: a gender perspective, Economics and Management: Current Issues and Perspectives, 1(14), 62-69.

Chien-Chi, C., Sun, B., Yang, H., Zheng, M., Li, B. 2020. Emotional Competence, Entrepreneurial Self-Efficacy, and Entrepreneurial Intention: A Study Based on China College Students' Social Entrepreneurship Project, Front. Psychol. 11 : 547627. https://doi.org10.3389/fpsyg.2020.547627

Chowdhury, F., Audretsch, D. B., Belitski, M. 2019. Institutions and Entrepreneurship Quality. Entrepreneurship Theory and Practice, 43(1), 51-81. https://doi.org/10.1177/1042258718780431

Eroğlu, O., Piçak, M. 2011. Entrepreneurship, National Culture and Turkey. International Journal of Business and Social Science, 2(16), 146-151.

European Commission/EACEA/Eurydice. 2016. Entrepreneurship Education at School in Europe. Eurydice Report. Luxembourg: Publications Office of the European Union.

Gaddam, S. 2008. Identifying the relationship between behavioral motives and entrepreneurial intentions: An empirical study based on the perceptions of business management students. The Icfaian Journal of Management Research, 7(5), 35-55.

Galloway, L., Kelly, S. 2009. Identifying entrepreneurial potential? An investigation of the identifiers and features of entrepreneurship, International Review of Entrepreneurship, 7(4), 1-24.

Gautam, M., K. Singh, S., K. 2015. Entrepreneurship education: concept, characteristics and implications for teacher education. Shaikshik Parisamvad (An International Journal of Education) SPIJE, 5(1), 21-35.

Griffiths, M., Kickul, J., Bacq, S., Terjesen, S. 2012. A Dialogue with William J. Baumol: Insights on Entrepreneurship Theory and Education, Entrepreneurship Theory and Practice, 36(4), 611-625.

Girdzijauskaite, E., Radzeviciene, A., Jakubavicius, A. 2019. Impact of international branch campus KPIs on the university competitiveness: FARE method. Insights into Regional Development, 1(2), 171-180. https://doi.org/10.9770/ird.2019.1.2(7)

Johann, D., Nunes, A., Santos, G., Silva, D., Bresciani, S., Lopes, L. 2020. Mapping of scientific production on design thinking as a tool for entrepreneurship education: a bibliometric study of a decade, World Journal of Entrepreneurship, Management and Sustainable Development, 16(4), 271-285. https://doi.org/10.1108/WJEMSD-05-2019-0028

Jones, C., English, J. 2004. A contemporary approach to entrepreneurship education, Education + Training, 46(8/9), 416-23.

Karimi, S., Biemans, H., Lans, T., Mulder, M., Chizari, M. 2012. The Role of Entrepreneurship Education in Developing Students' Entrepreneurial Intentions. Proceedings of WICaNeM 2012, The 10th Wageningen International Conference on Chain and Network Science, Wageningen University, Wageningen, The Netherlands, p. 22.

Kim, M., Lee, J., Roh, T., Son, H. 2020. Social Entrepreneurship Education as an Innovation Hub for Building an Entrepreneurial Ecosystem: The Case of the KAIST Social Entrepreneurship MBA Program, Sustainability, 12, 9736. https://doi.org/10.3390/su12229736

Kirby, D. 2004. Entrepreneurship education: can business schools meet the challenge? Education Training, 46(8/9), 510-19, http://dx.doi.org/10.1108/00400910410569632 


\section{ENTREPRENEURSHIP AND SUSTAINABILITY ISSUES}

ISSN 2345-0282 (online) http://jssidoi.org/jesi/

2021 Volume 8 Number 3 (March)

http://doi.org/10.9770/jesi.2021.8.3(10)

Make your research more visible, join the Twitter account of ENTREPRENEURSHIP AND SUSTAINABILITY ISSUES: @Entrepr69728810

Kowo, S. A., Adenuga, O. A. O., Sabitu, O.O. 2019. The role of SMEs development on poverty alleviation in Nigeria. Insights into Regional Development, 1(3), 214-226. https://doi.org/10.9770/ird.2019.1.3(3)

Küttim, M., Arvola, K., Venesaar, U. 2011. Development of creative entrepreneurship: opinion of managers from Estonia, Latvia, Finland and Sweden. Business: Theory and Practice, 12(4), 369-378 http://dx.doi.org/10.3846/btp.2011.38

Kuckertz, A., Berger, E.S.C., Prochotta, A. 2020. Misperception of entrepreneurship and its consequences for the perception of entrepreneurial failure - the German case, International Journal of Entrepreneurial Behavior \& Research, 26(8), 1865-1885. https://doi.org/10.1108/IJEBR-02-2020-0060

Lascaux, A., Kolesnikova, I. 2020. The emergence and evolution of cognition- and affect-based trust in Russian entrepreneurial ventures. Strategic entrepreneurship journal https://doi.org/10.1002/sej.1386

Liguori, E., Muldoon, J., Bendickson, J. 2020. Experiential entrepreneurship education via US films: why and how. Journal of Small Business and Enterprise Development, 27(6), 927-941. https://doi.org/10.1108/JSBED-04-2019-0135

Mahrous, A., Genedy, M.A., Kalliny, M. 2020. The impact of characteristics of intra-organizational environment on entrepreneurial marketing intensity and performance in Egypt. Journal of Entrepreneurship in Emerging Economies, 12(5), 621642. https://doi.org/10.1108/JEEE-08-2019-0115

Mani, M. 2015. Entrepreneurship Education: A Students' Perspective, International Journal of E-Entrepreneurship and Innovation, 5(1), $1-14$.

Miranda, C., Goñi, J., Berhane, B., Carberry, A. 2020. Seven Challenges in Conceptualizing and Assessing Entrepreneurial Skills or Mindsets in Engineering Entrepreneurship Education, Education Sciences, 10, 0309. https://doi.org/10.3390/educsci10110309

Muñoz-Castro, D.C., Santamaría-Alvarez, S., M., Marín-Zapata, S., I. 2019. Transnational entrepreneurship: a systematic review of the literature, International Journal of Entrepreneurship and Innovation Management, 23(6), 559-583. https://doi.org/10.1504/ijeim.2019.102824

Otache, I., Oluwade, D.O. and Idoko, E.-O.J. 2020. Entrepreneurship education and undergraduate students' self-employment intentions: do paid employment intentions matter?, Education + Training, 62(7/8), 741-757. https://doi.org/10.1108/ET-02-2020-0032

Peña-Ayala, A., Villegas-Berumen, H., G. 2020. Evaluation of the influence that higher education boosts on students' entrepreneurial proclivity: Evidence from Mexico and Spain. The International Journal of Management Education, 18(3) https://doi.org/10.1016/j.ijme.2020.100404

Peric, J., Peterka, O., Getoš, Ž. 2020. The role of vocational education in developing entrepreneurial Competences Of Students. Ekonomski Pregled, 71 (5), 463-492. https://doi.org/10.32910/ep.71.5.2

Raposo, M., Fernandes, C.I., Veiga, P.M. 2020. National systems of entrepreneurship: goals of sustainability, Journal of Entrepreneurship and Public Policy, 9(4), 345-364. https://doi.org/10.1108/JEPP-04-2020-0018

Rodriguez-Gutierrez, P., Cabeza-Ramírez, L., Muñoz-Fernández, G. 2020. University Students’ Behaviour towards Entrepreneurial Intention in Ecuador: Testing for the Influence of Gender, International Journal of Environmental Research and Public Health, $17,8475$. https://doi.org/10.3390/ijerph17228475

Schmitt, Ch., Husson, J. 2017. Entrepreneurial situations, definition and interests for entrepreneurial research, Int. J. Entrepreneurship and Small Business, 30(1). https://doi.org/10.1504/IJESB.2017.081037

Shyra, T., Shtyrov, O., Korchynskyy, I., Zerkal, A., Skoryk, H. 2020. Providing the corporate security strategy in the management system of the enterprise, Business: Theory and Practice, 21(2), 737-745. https://doi.org/10.3846/btp.2020.12975

Skulskis, V. 2012. Eco-farming and sowing, Economics and Management: Current Issues and Perspectives, 3(27), 37-44. 
ENTREPRENEURSHIP AND SUSTAINABILITY ISSUES

ISSN 2345-0282 (online) http://jssidoi.org/jesi/

2021 Volume 8 Number 3 (March)

http://doi.org/10.9770/jesi.2021.8.3(10)

Make your research more visible, join the Twitter account of ENTREPRENEURSHIP AND SUSTAINABILITY ISSUES: @Entrepr69728810

Sordi, J., S., Nelson, R., E., Meireles, M., Hashimoto, M., De Freitas Chagas Junior, M. 2020. A longitudinal study of the creation methods used by entrepreneurs to develop new products and services, International Journal of Entrepreneurship and Innovation Management (IJEIM), 24(6).

Stripeikis, O. 2008. Formation of entrepreneurship in Lithuanian small and medium business enterprises. http://vddb.library.lt/fedora/get/LT

Turner, C. 2004. Passion V Pension: Developing Corporate Entrepreneurship (Hardcover), 21st Century Books UK Ltd, p. 272.

Žibėnienè, G. 2014. Improving the qualifications of entrepreneurship teachers: current aspects and trends in Europe. Social Work, 11(2)

Wicham, P., A. 2006. Strategic entrepreneurship. Financial Times/Prentice Hall. 648 p. I.

Yu, Z. 2020. Visualizing Artificial Intelligence Used in Education Over Two Decades, Journal of Information Technology Research (JITR), 13(4). https://doi.org 10.4018/JITR.2020100103

\section{Acknowledgements}

The research is supported by University of Applied Sciences, Lithuania

Margarita IŠORAITE். Doctor of social sciences in Vilnius Gediminas Technical University, name of associated professor was given in Mykolas Romeris University in Lithuania. Associated professor in Vilnius kolegija/ University Applied Sciences. Research interests: human resource management, strategic marketing, marketing management, advertising, entrepreneurship.

ORCID ID: https://orcid.org/0000-0001-9108-0525

Gintarė GULEVIČIŪTE் is a lecturer. She received M. Sc. in Electronic Business Management from Mykolas Romeris University. Her areas of interest are e-business, e-marketing, entrepreneurship, business communication and digital contents.

ORCID ID: https://orcid.org/0000-0003-1974-3982

Register for an ORCID ID:

https://orcid.org/register

Copyright (C) 2021 by author(s) and VsI Entrepreneurship and Sustainability Center

This work is licensed under the Creative Commons Attribution International License (CC BY).

http://creativecommons.org/licenses/by/4.0/

c. (i) Open Access 